\title{
EFEKTIVITAS KINERJA MEDIA BIOFILTER DALAM SISTEM RESIRKULASI TERHADAP KUALITAS AIR UNTUK PERTUMBUHAN DAN SINTASAN IKAN RED RAINBOW (Glossolepis incisus Weber)
}

\author{
Nurhidayat"), Kukuh Nirmala*), dan D. Djokosetyanto ${ }^{* *}$ \\ *) Balai Penelitian dan Pengembangan Budidaya Ikan Hias \\ Jl. Perikanan No. 13, Pancoran Mas, Depok 16436 \\ E-mail:publikasi.bppbih@gmail.com \\ *) Institut Pertanian Bogor \\ JI. Raya Dermaga, Kampus IPB Darmaga, Bogor 16680
}

(Naskah diterima: 13 April 2011; Disetujui publikasi: 9 Juli 2012)

\begin{abstract}
ABSTRAK
Penelitian ini bertujuan untuk mengetahui efektivitas kinerja media biofilter zeolit dan bioball dalam perbaikan kualitas air yang akan meningkatkan pertumbuhan dan sintasan ikan red rainbow (Glossolepis incisus Weber) pada sistem resirkulasi. Wadah percobaan berupa akuarium dengan ukuran $100 \mathrm{~cm} \times 60 \mathrm{~cm} \times 40 \mathrm{~cm}$ sebanyak 24 buah, masing-masing ditebar ikan sebanyak 60 ekor/akuarium. Ikan uji yang digunakan dengan bobot awal $0,71 \mathrm{~g}$ dan panjang $3,51 \mathrm{~cm}$. Perlakuan yang digunakan dalam percobaan adalah media biofilter: A. zeolit 100\%, B. zeolit $75 \%$ + bioball $25 \%$, C. zeolit $50 \%+$ bioball $50 \%$, D. zeolit $25 \%$ + bioball $75 \%$, E. bioball $100 \%$, dan F. kontrol. Pakan yang digunakan adalah pelet komersial, diberikan $5 \%$ dari bobot total ikan yang diberikan sebanyak tiga kali (pagi, siang, dan sore). Percobaan disusun dalam Rancangan Acak Lengkap (RAL), dengan enam perlakuan yang diulang sebanyak empat kali. Hasil pengamatan perlakuan media biofilter zeolit $75 \%$ + bioball $25 \%$ memberikan kualitas air terbaik dengan kualitas baik (kategori IV), dengan efektivitas oksidasi amonia sebesar $95,03 \pm 0,31 \%$ dan biomassa bakteri non patogen (nitrifikasi) dengan jumlah koloni $(8,6 \pm 1,91) \times 10^{6}$. Pertumbuhan panjang total dan sintasan yang diperoleh $66,67 \%(2,34 \mathrm{~cm})$ dan $96,67 \%$.
\end{abstract}

KATA KUNCI: pertumbuhan, red rainbow, biofilter, kualitas air, resirkulasi

ABSTRACT: Biofilter performance effectiveness on water quality, growth performance and survival rate improvement of red rainbow fish (Glossolepis incisus Weber) reared in recycled water system. By: Nurhidayat, Kukuh Nirmala, and D. Djokosetyanto

The objective of this research was to determine the effectiveness of zeolit and bioball performance on water quality improvement, that will increase growth and survival rate of red rainbow fish (Glossolepis incisus Weber) reared in recycled water system. Red rainbow fish with initial body weight $0.71 \mathrm{~g}$ and length $3.51 \mathrm{~cm}$ were stocked on 24 aquaria $(100 \mathrm{~cm} \times 60 \mathrm{~cm} \times 40 \mathrm{~cm})$ at a stocking density 60 individuals/aquarium. The treatment that were used at this research i.e. A. zeolit 100\%, B. zeolit $75 \%+$ bioball 25\%, C. zeolit 50\% + bioball 50\%, D. zeolit 25\% + bioball 75\%, E. bioball 100\%, and F. control. Commercial food was used as feed at this research. The daily feeding rate was divided three allowances fed to the red rainbow fish at morning, noon, and evening, in which the feeding dosage were $5 \%$ of total body weight. Complete Randomized Design (CRD) was used at this experiment, with six treatment and four 
times replication. Result showed that zeolit $75 \%+$ bioball $25 \%$ treatment, gave the best result of water quality at good quality (category IV), with effectiveness ammonia oxsidation was $95.03 \pm 0.31 \%$ and the colonies of non pathogenic bacterial biomass (nitrification) were $(8.6 \pm 1.91) \times 10^{6}$. Survival rate and total length performance that was obtained at this research were $96.67 \%$ and $66.67 \%(2.34 \mathrm{~cm})$.

\section{KEYWORDS: growth, red rainbow, biofilter, water quality, recirculation}

\section{PENDAHULUAN}

Selama dua dekade kegiatan budidaya perikanan telah mengalami perubahan yang utama, berkembang dari skala rumah tangga ke skala besar-besaran yang berorientasi komersial (FAO/NACA, 2001 dalam Gutierrez $\&$ Malone, 2006). Peningkatan produksi akuakultur terus mengarah ke arah aplikasi yang lebih intensif. Beberapa faktor yang mempengaruhi kecenderungan ini adalah; terbatasnya mutu dan kualitas air, berkurangnya lahan serta pembatasan karena dampak lingkungan. Beberapa tahun terakhir buangan limbah khususnya budidaya semakin tinggi, hal ini berdampak terhadap penurunan kualitas air terutama budidaya. Setiap tahun akibat pertumbuhan kegiatan budidaya yang terus berkembang, diperkirakan terjadi buangan berupa fosfor sebesar $85 \%, 80 \%-88 \%$ karbon, nitrogen $52 \%-95 \%$, dan $60 \%$ berupa buangan dari sisa pakan berbentuk partikel, bahan kimia terlarut dan gas terbuang ke badan air (Masser et al., 1999).

Kandungan amonia yang terlarut di dalam air akan meningkatkan kebutuhan oksigen biokimia BOD (biochemical oxygen demand), selama proses oksidasi amonia, (Soemantojo, 1998). Amonia adalah sumber energi bagi bakteri autotropik yang menggunakan kadar alkali untuk membangun material sel. Amonia pertama kali dikonversi menjadi nitrit oleh kelompok bakteri Nitrosomonas sp. dan kemudian dikonversi lagi menjadi nitrat oleh bakteri Nitrobacter sp. amonia bebas yang tidak terionisasi $\left(\mathrm{NH}_{3}\right)$ sebaiknya tidak melebihi 0,02 mg/L. Menurut Sawyer \& Mc Carty (1978), kadar amonia bebas melebihi $0,2 \mathrm{mg} / \mathrm{L}$ bersifat toksik bagi ikan. Nitrat tidak bersifat toksik terhadap organisme akuatik, konsumsi air yang mengandung kadar nitrat tinggi mengakibatkan penurunan kapasitas darah dalam mengikat oksigen. Pada kondisi oksigen rendah, amonia yang dihasilkan melalui proses penguraian bahan organik maupun sekresi langsung ikan akan sulit mengalami proses penguraian lebih lanjut. Akumulasi amonia dan ketersediaan oksigen pada tingkat konsentrasi $0,18 \mathrm{mg} / \mathrm{L}$ dapat menghambat pertumbuhan (Wedemeyer, 1996). Perubahan parameter kualitas air media budidaya dapat menyebabkan menurunnya kualitas media budidaya, hal ini harus diperhatikan penggunaan dan pengelolaannya. Salah satu pengelolaan kualitas air dapat digunakan untuk mempertahankan kualitas air tetap optimum, salah satunya adalah sistem resirkulasi dan purifikasi.

Sistem resirkulasi adalah salah satu jawaban untuk menjaga kualitas air tetap optimal selama pemeliharaan ikan di dalam wadah. Resirkulasi adalah sistem yang menggunakan air secara terus-menerus dengan cara diputar untuk dibersihkan di dalam filter kemudian dialirkan kembali ke wadah budidaya. Memelihara ikan pada sistem resirkulasi selalu dihadapkan pada masalah penumpukkan bahan organik (feses/sisa pakan), anorganik (amonia, nitrit, nitrat) yang terlarut dan terbatasnya oksigen terlarut (Tanjung, 1994). Menurut Muir (1994), rancangan sistem yang tepat dan cara perlakuan yang terpadu dengan memastikan efektivitas setiap tahapan perlakuan dan keterpaduan sistem secara keseluruhan akan menyempurnakan sistem.

Filter yang digunakan dalam sistem resirkulasi berperan sebagai media untuk menempelnya bakteri yang akan memanfaatkan bahan-bahan organik berupa sisa pakan dan buangan metabolisme sebagai energi. Sistem resirkulasi sebaiknya menggunakan bahan filter yang dapat berfungsi secara ganda, di mana proses biologi, fisika, dan kimia dapat berjalan di dalamnya. Bahan yang dapat berperan ganda antara lain: batu karang, zeolit, dan kulit kerang, bahan ini mempunyai fungsi ganda selama proses oksidasi. Peran yang dapat dilakukan bahan ini adalah kemampuan secara kimia yaitu dalam penyerapan ion, secara biologi media ini mampu memberikan tempat untuk menempel bakteri atau sebagai media biofilter. Zeolit 
merupakan batuan alam sebagai sumberdaya alam yang berlimpah di Indonesia, sehingga mudah diperoleh dengan harga yang murah. Batuan ini mempunyai banyak manfaat, salah satunya sebagai penyerap amonium di instalasi air minum dan pengolahan instalasi limbah pabrik sebagai media penyerap amoniak dan limbah lainnya. Menurut Las (2007), zeolit merupakan filter kimia yang banyak dimanfaatkan untuk penjernihan air limbah terutama dalam penyerapan amonium, nitrit, nitrat, dan $\mathrm{H}_{2} \mathrm{~S}$. Selain bekerja secara kimiawi, dengan luas dan permukaan yang kasar diharapkan zeolit dapat digunakan sebagai biofilter, di mana mikroorganisme pendegradasi bahan organik dan anorganik menempel. Bioball merupakan bahan sintesis yang banyak digunakan sebagai filter, bahan ini mempunyai harga cukup tinggi yang kurang terjangkau bagi petani dengan modal kecil, sehingga penggunaannya terbatas pada pembudidaya dengan modal besar. Turunnya kualitas air di wadah budidaya akibat sisa buangan berupa sisa pakan dan metabolisme bisa dikurangi dengan melakukan penggantian air, penggantian air yang sering dilakukan merupakan salah satu pemborosan. Untuk itu, diperlukan upaya mempercepat proses penguraian bahan organik dan anorganik yang berasal dari buangan metabolisme dan sisa pakan sebelum mencapai tingkat tercemar. Tujuan penelitian ini adalah mengukur efektivitas media biofilter dalam memperbaiki kualitas air terhadap kinerja pertumbuhan dan sintasan ikan red rainbow (Glossolepis incises Weber) dalam sistem resirkulasi.

\section{BAHAN DAN METODE}

Penelitian ini dilaksanakan di Laboratorium Lingkungan Balai Penelitian dan Pengembangan Budidaya Ikan Hias (BPPBIH) Depok. Metode penelitian yang digunakan adalah metode eksperimen yang dilaksanakan di laboratorium. Rancangan yang digunakan adalah Rancangan Acak Lengkap (RAL) dengan lima taraf perlakuan dan satu kontrol, di mana masing-masing perlakuan diulang sebanyak empat kali. Langkah awal untuk menjalankan sistem resirkulasi dilakukan penambahan pakan berupa pelet komersial ke dalam sistem yang berjalan sebanyak $15 \mathrm{~g} /$ filter, pakan tersebut diberikan untuk memberikan unsur amonia sehingga bakteri dapat tumbuh dalam sistem tersebut. Sistem akan berjalan dengan siklus pertumbuhan dan kehidupan bakteri yang akan optimum dalam 7-15 hari. Berjalannya sistem ditandai adanya perubahan kualitas air berupa fluktuasi kadar amonia, nitrit, dan nitrat, serta adanya koloni bakteri. Satuan percobaan yang dicobakan sebagai perlakuan adalah: A. (100\% zeolit), B. (25\% bioball $+75 \%$ zeolit), C. ( $50 \%$ bioball $+50 \%$ zeolit), D. (75\% bioball + $25 \%$ zeolit), E. (100\% bioball), dan F. kontrol (dakron). Selengkapnya sistem resirkulasi yang digunakan disajikan di Gambar 1.

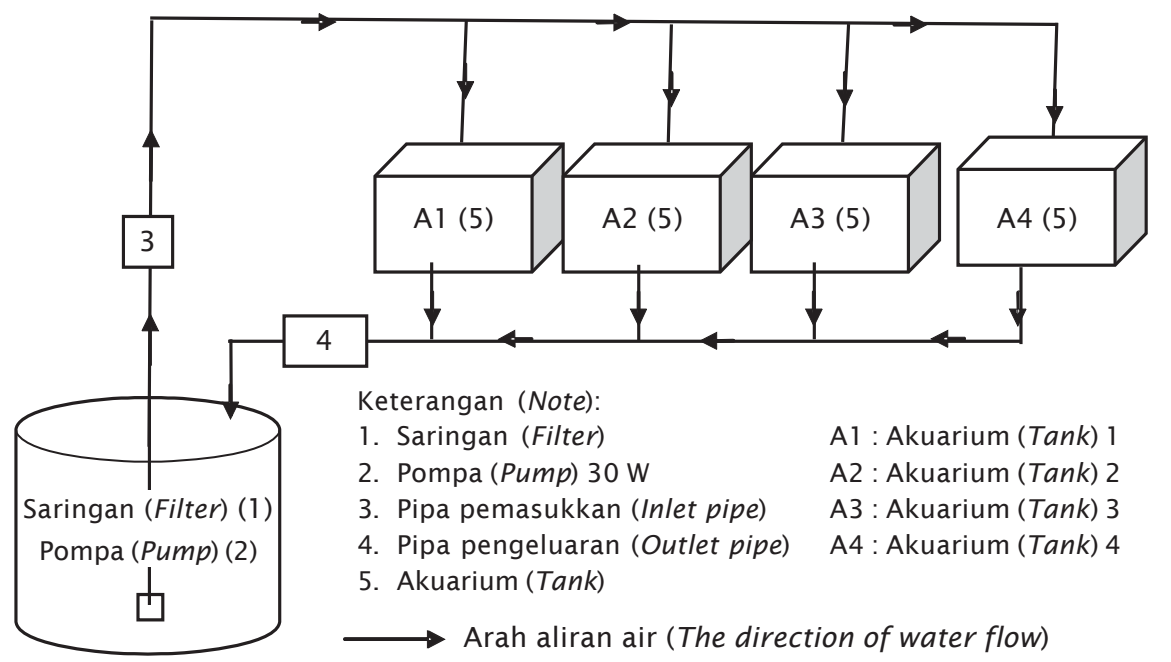

Gambar 1. Skema unit resirkulasi

Figure 1. The scheme of recirculation unit 


\section{Sistem Resirkulasi}

\section{Spesifikasi Sistem Resirkulasi}

Sistem resirkulasi dibangun dengan rincian sebagai berikut:

1. Akuarium ukuran $90 \mathrm{~cm} \times 60 \mathrm{~cm} \times 50 \mathrm{~cm}$ sebanyak 4 buah

2. Pompa ukuran 18 watt

3. Filter yang digunakan adalah: dakroon, bioball, zeolit, masing-masing filter bioball dengan ukuran 1 inci, zeolit dengan mesh $1 \mathrm{~cm}$. Untuk menyeragamkan zeolit yang digunakan dilakukan penyortiran dengan kawat kasa dengan ukuran mata 1,25 cm.

\section{Media Biofilter yang Digunakan}

Media Biofilter yang digunakan berupa zeolit yang mempunyai ukuran seragam, penyeragaman dilakukan dengan cara penyortiran dengan saringan yang mempunyai mesh yang sudah ditetapkan. Untuk memberikan volume media biofilter yang digunakan sama untuk setiap sistem dilakukan pengukuran volume. Banyaknya media biofilter yang digunakan disesuaikan dengan perbandingan dari perlakuan yang diberikan. Setiap filter berisi biofilter sebanyak $30 \mathrm{~L}$, sehingga untuk perlakukan A. (100\% zeolit), diisi zeolit sebanyak 30 L, B. ( $25 \%$ bioball + 75\% zeolit) berisi 7,5 L bioball dan $15 \mathrm{~L}$ zeolit dan begitu seterusnya. Gambar media filter yang digunakan berupa zeolit dan bioball sebagai media biofilter disajikan pada Gambar 2.

\section{Debit Air}

Sistem resirkulasi bertujuan untuk memperbaiki kualitas air dengan cara melakukan pemutaran air untuk disaring di media biofilter. Proses ini memerlukan arus yang sesuai sehingga sistem yang digunakan dapat bekerja secara optimal. Sistem yang digerakkan mempunyai laju debit air $2 \mathrm{~L} /$ detik. Pengaturan debit air dilakukan dengan saluran output menggunakan keran air sehingga mampu untuk menghasilkan debit sesuai kebutuhan.

\section{Teknik Pengumpulan Data}

Pengambilan dan pengamatan kualitas air untuk melihat kinerja media biofilter dilakukan setiap satu minggu. Metode analisis dan pengawetan contoh tercantum pada Tabel 1.

\section{Pelaksanaan Percobaan}

Percobaan dilakukan dalam dua tahap, yaitu percobaan pendahuluan dan percobaan utama.

\section{Percobaan Pendahuluan}

Percobaan pendahuluan ini dilakukan untuk menentukan ukuran masing-masing bahan filteryang digunakan dapat berfungsi dengan baik sehingga mampu memaksimalkan biomassa bakteri non-patogen (bakteri nitrifikasi). Sedangkan unit sistem resirkulasi yang digunakan adalah sistem yang dibangun sesuai prinsip resirkulasi. Percobaan pendahuluan dilaksanakan selama 30 hari tanpa dipelihara ikan, sebagai penyumbang bahan organik dilakukan pemberian pakan pelet komersial sebanyak $15 \mathrm{~g} /$ sistem. Pemberian pelet yang dilakukan dengan asumsi untuk satu sistem yang dipelihara ikan dengan bobot total $300 \mathrm{~g}$, apabila ikan diberikan pakan sebanyak $5 \%$ dari bobot total sehingga diperoleh angka $15 \mathrm{~g}$. Pengambilan sampel dilakukan 10 hari sekali selama 30 hari. Parameter yang diamati adalah fluktuasi amonia, nitrit, nitrat, $\mathrm{BOD}_{5}, \mathrm{O}_{2}$, alkalinitas, $\mathrm{pH}, \mathrm{CO}_{2}$.

\section{Percobaan Utama}

Sistem resirkulasi skala laboratorium yang digunakan untuk percobaan utama merupakan sistem yang telah digunakan pada percobaan pendahuluan. Setelah sistem resirkulasi siap, ikan dimasukkan ke dalam media pemeliharaan unit resirkulasi sebanyak 100 ekor/50 L. Pemeliharaan dilakukan selama 60 hari, selama proses berjalan ikan diberi pakan komersial. Jumlah pakan yang diberikan sebanyak $5 \%$ dari total bobot badan ikan, dengan frekuensi tiga kali sehari. Pengambilan sampel dilakukan setiap 10 hari sekali selama 60 hari.

\section{Desain dan Waktu Evaluasi}

Percobaan dilakukan selama tiga bulan, evaluasi sistem dilakukan terhadap $\mathrm{BOD}_{5}$, efisiensi amonia, nitrit, nitrat, DO. Sebagai parameter penunjang dilakukan analisis: pertumbuhan ( $\mathrm{mm}, \mathrm{g})$, sintasan (SR), dan konversi pakan (FCR) dilakukan setiap perlakuan. Pengukuran parameter kualitas air untuk menentukan kandungan amonia, nitrat, nitrit, $\mathrm{BOD}_{5}$ dilakukan di inlet dan outlet. Pengukuran ini dilakukan untuk mengukur efektivitas oksidasi bahan organik yang terdapat dalam sistem resirkulasi. Pengukuran 

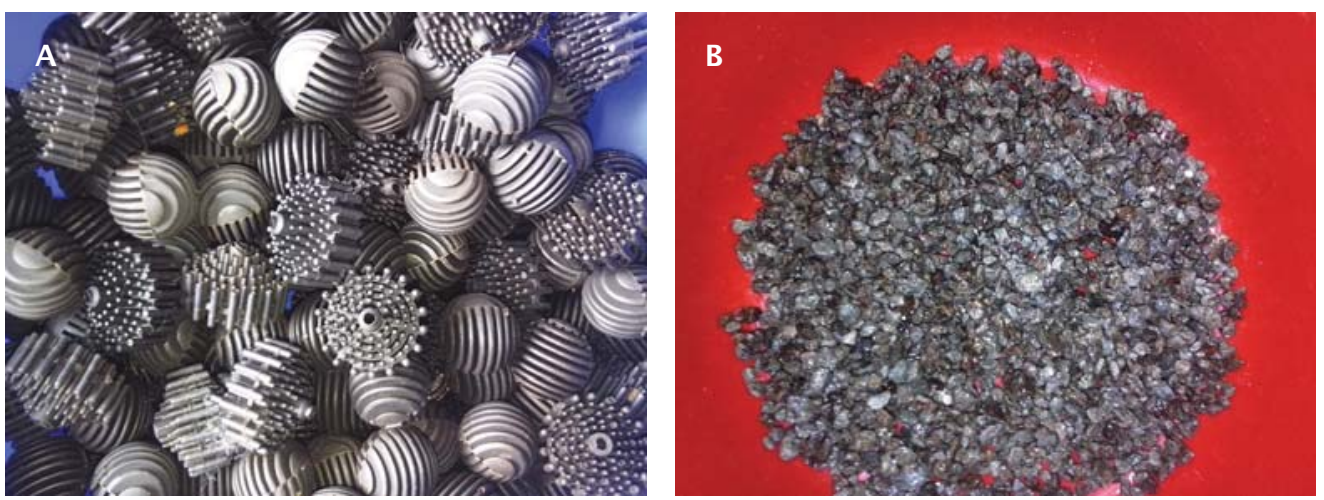

Gambar 2. Bioball (A) dan zeolit (B) yang digunakan sebagai biofilter

Figure 2. Bioball (A) and zeolit (B) are used as biofilter

Tabel 1. Metode analisis sampel dan parameter yang diamati

Table 1. The analysis methods and parameters of the observed sample

\begin{tabular}{|c|c|c|c|}
\hline $\begin{array}{l}\text { Parameter } \\
\text { Parameters }\end{array}$ & $\begin{array}{l}\text { Satuan } \\
\text { Unit }\end{array}$ & $\begin{array}{l}\text { Alat ukur } \\
\text { Measuring instrument }\end{array}$ & $\begin{array}{l}\text { Metode analisis } \\
\text { Methods of analysis }\end{array}$ \\
\hline \multicolumn{4}{|l|}{ Air (Water) } \\
\hline $\begin{array}{l}\text { Suhu } \\
\text { Temperature }\end{array}$ & ${ }^{\circ} \mathrm{C}$ & $\begin{array}{l}\text { Termometer (minimal-maksimal) } \\
\text { Thermometer (minimal-maximal) }\end{array}$ & $\begin{array}{l}\text { Langsung } \\
\text { Directly }\end{array}$ \\
\hline $\mathrm{BOD}_{5}$ & $\mathrm{mg} / \mathrm{L}$ & $\begin{array}{l}\text { Inkubasi } 20^{\circ} \mathrm{C} \text {, Titrimetrik } \\
\text { Incubation } 20^{\circ} \mathrm{C} \text {, Titrimetric }\end{array}$ & $\begin{array}{l}\text { Langsung } \\
\text { Directly }\end{array}$ \\
\hline $\begin{array}{l}\text { Amonia-N } \\
N \text {-Ammonium }\end{array}$ & $\mathrm{mg} / \mathrm{L}$ & $\begin{array}{l}\text { Spektrofotometer } \\
\text { Spectrophotometer }\end{array}$ & $\begin{array}{l}\text { Langsung } \\
\text { Directly }\end{array}$ \\
\hline $\begin{array}{l}\text { Oksigen terlarut } \\
\text { Dissolved oxygen }\end{array}$ & $\mathrm{mg} / \mathrm{L}$ & DO meter & $\begin{array}{l}\text { Langsung } \\
\text { Directly }\end{array}$ \\
\hline $\begin{array}{l}\text { Nitrit-N } \\
\text { N-Nitrite }\end{array}$ & $\mathrm{mg} / \mathrm{L}$ & $\begin{array}{l}\text { Spektrofotometer } \\
\text { Spectrophotometer }\end{array}$ & $\begin{array}{l}\text { Langsung } \\
\text { Directly }\end{array}$ \\
\hline $\begin{array}{l}\text { Nitrat-N } \\
N \text {-Nitrate }\end{array}$ & $\mathrm{mg} / \mathrm{L}$ & $\begin{array}{l}\text { Spektrofotometer } \\
\text { Spectrophotometer }\end{array}$ & $\begin{array}{l}\text { Langsung } \\
\text { Directly }\end{array}$ \\
\hline $\begin{array}{l}\text { Alkalinitas total } \\
\text { Total alkalinity }\end{array}$ & $\mathrm{mg} \mathrm{CaCO} / \mathrm{L}$ & Titrasi (Titration) & $\begin{array}{l}\text { Langsung } \\
\text { Directly }\end{array}$ \\
\hline $\mathrm{pH}$ & & $\mathrm{pH}$ meter & $\begin{array}{l}\text { Langsung } \\
\text { Directly }\end{array}$ \\
\hline $\mathrm{CO}_{2}$ & $\mathrm{mg} / \mathrm{L}$ & Titrasi (Titration) & $\begin{array}{l}\text { Langsung } \\
\text { Directly }\end{array}$ \\
\hline \multicolumn{4}{|l|}{ Biologi (Biology) } \\
\hline $\begin{array}{l}\text { Bakteri } \\
\text { Bacteria }\end{array}$ & $\mathrm{cfu} / \mathrm{mL}$ & $\begin{array}{l}\text { Plate Count, gram positif-ne gatif } \\
\text { Plate Count, positive-negative gram }\end{array}$ & $\begin{array}{l}\text { Langsung } \\
\text { Directly }\end{array}$ \\
\hline Ikan (panjang, bobot) & & Timbangan elektrik, milimeter blok & Langsung \\
\hline $\begin{array}{l}\text { Fishes (total length, } \\
\text { weight) }\end{array}$ & $\mathrm{mm} ; \mathrm{g}$ & Electronic scales, millimeter blocks & Directly \\
\hline
\end{tabular}


dilakukan setiap minggu, sedangkan parameter untuk ikan seperti: panjang, bobot, kematian dilakukan pengukuran di setiap akuarium setiap 15 hari.

$$
\begin{aligned}
\text { Efisiensi Amonia }\left(\mathrm{NH}_{3}\right) \text { (\%) } \\
\mathrm{NH}_{3 \text { (remova) }}=\mathrm{NH}_{3 \text { (filter inlet) }}-\mathrm{NH}_{3 \text { (filter outlet) }} \\
\text { (\%) } \mathrm{NH}_{3 \text { (remova) }}=\left(\mathrm{NH}_{3 \text { (remova) }} / \mathrm{NH}_{3 \text { (filter inlet) }}\right) \times 100 \%
\end{aligned}
$$

(Mc Carty \& Haug, 1971)

Efektivitas oksidasi bahan organik menggunakan parameter reduksi amonia dalam sistem yang diukur di inlet dan outlet sistem resirkulasi. Parameter yang diukur dalam proses tersebut adalah $\mathrm{NH}_{3 \text { inlet }}-\mathrm{NH}_{3 \text { outlet, }}$, hasil yang diperoleh akan dihitung berdasar persamaan efisiensi amonia dengan persamaan Mc Carty \& Haug (1971). Selain reduksi amonia dilakukan juga pengukuran $\mathrm{BOD}_{5}$ untuk mengetahui kinerja bakteri dalam menggunakan oksigen terlarut.

\section{Pembagian Kategori Kualitas Air}

Kualitas air yang dihasilkan dievaluasi berdasarkan pendekatan metode cheklist berskala dengan pembobotan, kualitas air yang diperoleh selama percobaan dibandingkan secara kuantitatif. Menurut Loren \& Carter (1979) dalam Azwar (1984), tahap pertama yang dilakukan adalah dengan mengkategorikan individu kualitas air ke dalam unitunit yang sifatnya sama (Tabel 2), kemudian ditransfer ke dalam suatu skala kualitas lingkungan (EQ). Langkah kedua memberikan skala EQ berdasarkan individu parameter, selengkapnya disajikan pada Tabel 3.

Selanjutnya menentukan skala kepentingan tiap individu parameter, yaitu nilai kepentingan suatu komponen yang menggambarkan peranan dalam kualitas lingkungan. Makin besar nilai kepentingan berarti semakin besar peran individu parameter dalam lingkungan.

Langkah ketiga adalah menentukan rasio kepentingan $\mathrm{O}_{2}: \mathrm{BOD}_{5}: \mathrm{NH}_{3}(\mathrm{mg} / \mathrm{L})=1: 0.8$ : 0,5

$$
\begin{aligned}
& \mathrm{PIU} \mathrm{O}_{2}=1 / 2.3 \times 10=4 \text { (dibulatkan) } \\
& \mathrm{PIU} \mathrm{NH}_{3}=1 / 2.3 \times 10=3 \text { (dibulatkan) } \\
& \text { PIU BOD }_{5}=1 / 2.3 \times 10=3 \text { (dibulatkan) }
\end{aligned}
$$

Langkah keempat menentukan tingkat kualitas air berdasarkan:

Tabel 2. Skala kelas kualitas air sesuai kriteria

Table 2. The scale of water quality classes according to the criteria

\begin{tabular}{ccl}
\hline $\begin{array}{c}\text { Skala kelas } \\
\text { Class scale }\end{array}$ & $\begin{array}{c}\text { Kisaran nilai kualitas air } \\
\text { Value range of water quality (EQ) }\end{array}$ & $\begin{array}{c}\text { Krit eria kualitas } \\
\text { Quality criteria }\end{array}$ \\
\hline 1 & $0.00-0.19$ & Sangat buruk (Very bad) \\
2 & $0.20-0.39$ & Buruk (Bad) \\
3 & $0.40-0.59$ & Sedang (Not bad) \\
4 & $0.60-0.79$ & Baik (Good) \\
5 & $0.80-1.00$ & Sangat baik (Very good) \\
\hline
\end{tabular}

Sumber (Source): Loren \& Carter (1979) dalam (in) Azwar (1984)

Tabel 3. Kriteria pemberian skala EQ berdasarkan satuan parameter

Table 3. Criteria of EQ scale based on the parameter unit

\begin{tabular}{lccccc}
\hline $\begin{array}{c}\text { Parameter lingkungan } \\
\text { Environmental } \\
\text { parameters }\end{array}$ & $\mathbf{1}$ & $\mathbf{2}$ & $\mathbf{3}$ & $\mathbf{4}$ & $\mathbf{5}$ \\
\cline { 2 - 6 } & $0.00-3.00$ & $3.00-4.50$ & $4.50-5.50$ & $5.50-6.50$ & $6.50-7.50$ \\
\hline $\mathrm{O}_{2}(\mathrm{mg} / \mathrm{L})$ & 5.00 & $5.00-3.00$ & $3.00-2.00$ & $2.00-1.00$ & $1.00-0.00$ \\
$\mathrm{BOD}_{5}(\mathrm{mg} / \mathrm{L})$ & $0.08-0.10$ & $0.06-0.08$ & $0.04-0.06$ & $0.02-0.04$ & $0.00-0.02$ \\
$\left.\mathrm{NH}_{3}(\mathrm{mg} / \mathrm{L}) / \mathrm{L}\right)$ & & & &
\end{tabular}


$X=\frac{\left(\left(\mathrm{PIU} \mathrm{O}_{2} \times \mathrm{K}\right)+\left(\mathrm{PIU} \mathrm{BOD}_{5} \times \mathrm{K}\right)+\left(\mathrm{PIU} \mathrm{NH}_{3} \times \mathrm{K}\right)\right)}{(\Sigma \mathrm{PIU} \times 5)}$

di mana:

$X=$ Tingkat kualitas air

$\mathrm{PIU}=$ Bobot kepentingan individu parameter

$\mathrm{K}=$ Nilai EQ

$5=$ Nilai kelas air tertinggi

\section{Pertumbuhan dan Sintasan}

\section{Pertumbuhan}

Pertumbuhan bobot mutlak atau nisbi: (Weatherley, 1972).

$$
h=W_{t}-W_{o}
$$

di mana:

$\mathrm{h}=$ Perubahan bobot mutlak atau total tubuh ikan selama percobaan $(\mathrm{g})$

$\mathrm{W}_{\mathrm{t}}=$ Total bobot badan awal percobaan $(\mathrm{g})$

$\mathrm{W}_{\mathrm{o}}=$ Total bobot badan selama percobaan $(\mathrm{g})$

\section{Laju Pertumbuhan Harian}

Laju pertumbuhan harian (a) dihitung berdasarkan rumus dari Effendie (2002), yaitu:

$$
a=\sqrt[t]{\frac{W_{t}}{W_{0}}}-1 \times 100 \%
$$

di mana:

$$
\begin{aligned}
& \mathrm{a}=\text { Laju pertumbuhan harian (\% bobot badan/hari) } \\
& \mathrm{W}_{\mathrm{t}}=\text { Bobot rata-rata individu pada akhir penelitian }(\mathrm{g}) \\
& \mathrm{W}_{\mathrm{o}}=\text { Bobot rata-rata individu pada awal penelitian }(\mathrm{g}) \\
& \mathrm{t}=\text { Lama penelitian (hari) }
\end{aligned}
$$

\section{Analisis Data}

Data yang diperoleh berupa kualitas air dianalisis secara deskriptif dalam bentuk gambar dan grafik. Untuk nilai efisiensi (oksidasi) amonia, sintasan, pertumbuhan, FCR, dan koloni bakteri dilakukan uji sidik ragam (ANOVA), apabila terjadi perbedaan yang nyata antar perlakuan dilakukan uji lanjut dengan uji LSD (uji t) menggunakan program SPSS versi 12.0.

\section{HASIL DAN BAHASAN}

\section{Percobaan Pendahuluan}

Percobaan pendahuluan dilakukan untuk mengetahui media biofilter yang digunakan dapat digunakan secara optimum, kondisi tersebut dapat dilihat dengan adanya kinerja media biofilter yang ditandai adanya kinerja bakteri. Kinerja tersebut dapat dilihat dengan adanya kelimpahan koloni bakteri pada percobaan pendahuluan selama pengamatan tiga minggu menunjukkan jumlah koloni bakteri untuk zeolit adalah $(2,41 \pm 0,20$ $2,79 \pm 0,20) \times 10^{3} \mathrm{cfu} / \mathrm{mL}$; sedangkan filter bioball $(3,30 \pm 1,91-6,70 \pm 1,91) \times 10^{3} \mathrm{cfu} / \mathrm{mL}$; dan serat kapas dengan kelimpahan bakteri $(1,85 \pm 0,24-2,29 \pm 0,24) \times 10^{3} \mathrm{cfu} / \mathrm{mL}$. Selengkapnya kelimpahan bakteri selama percobaan pendahuluan setiap minggu disajikan pada Tabel 4.

Hasil pengamatan percobaan pendahuluan menunjukkan terjadi kinerja media biofilter yang mereduksi bahan organik ditandai adanya fluktuasi parameter seperti amonia, nitrit, dan nitrat. Kelimpahan bakteri tertinggi selama percobaan diperoleh dari media biofilter bioball hal ini membuktikan bioball mempunyai ruang dan tempat yang lebih untuk menempel bakteri dalam membentuk biofilm. Parameter kualitas air selama percobaan pendahuluan selengkapnya disajikan pada Tabel 5.

Hasil pengamatan kualitas air memberikan informasi selama percobaan, parameter suhu yang ada pada kisaran $28^{\circ} \mathrm{C}-31^{\circ} \mathrm{C}$. Menurut Yosida (1967) dalam Spotte (1979), bahwa suhu optimum untuk pertumbuhan bakteri nitrifikasi adalah pada suhu $27^{\circ} \mathrm{C}-28^{\circ} \mathrm{C}$. Hal ini menunjukkan suhu yang diperoleh selama percobaan dapat memberikan kondisi optimum. Kadar oksigen terlarut di dalam sistem mempunyai nilai yang cukup bahkan mencapai batas supersaturation, hal ini ada kaitannya dengan adanya aliran dalam sistem dan penambahan aerasi. Kadar oksigen terlarut dalam air dibutuhkan oleh mikroorganisme selama proses dekomposisi bahan organik, kebutuhan ini dikenal dengan nilai BOD $_{5}$. Nilai yang diperoleh menunjukkan terjadinya pemanfaatan oksigen oleh mikroba selama proses dekomposisi bahan organik terutama bakteri, proses dekomposisi paling tinggi diperoleh dari kombinasi media biofilter $75 \%$ zeolit dengan 25\% bioball. Selama proses dekomposisi dibutuhkan bahan organik yaitu amonia yang dibutuhkan sebagai bahan energi oleh bakteri. Selama percobaan pendahuluan terjadi perubahan nilai amonia, nitrit, dan nitrat, hal ini berarti di dalam sistem yang berjalan terjadi proses dekomposisi bahan organik oleh bakteri. Selama proses dekomposisi kinerja bakteri juga dipengaruhi oleh media biofilter 
Tabel 4. Kelimpahan bakteri selama percobaan pendahuluan

Table 4. The abundance of bacteria during preliminary experiments

\begin{tabular}{lccc}
\hline \multirow{2}{*}{$\begin{array}{c}\text { Saringan } \\
\text { Filter }\end{array}$} & \multicolumn{3}{c}{$\begin{array}{c}\text { Kelimpahan bakteri (minggu) } \\
\text { Bacteria abundance (week) } \\
\left(\mathbf{1 0}^{3} \text { cfu/mL) }\right.\end{array}$} \\
\cline { 2 - 4 } & $\mathbf{1}$ & $\mathbf{2}$ & $\mathbf{3}$ \\
\hline Zeolit & $2.79 \pm 0.20$ & $2.41 \pm 0.20$ & $2.73 \pm 0.20$ \\
Bioball & $6.70 \pm 1.91$ & $3.30 \pm 1.91$ & $6.50 \pm 1.91$ \\
Serat kapas (Dacroon) & $1.85 \pm 0.24$ & $1.90 \pm 0.24$ & $2.29 \pm 0.24$ \\
\hline
\end{tabular}

Tabel 5. Kisaran nilai kualitas air pada berbagai filter selama percobaan pendahuluan Table 5. The range of water quality values of various filter for preliminary experiments

\begin{tabular}{|c|c|c|c|c|c|c|}
\hline \multirow{2}{*}{$\begin{array}{l}\text { Parameter } \\
\text { Parameters }\end{array}$} & \multicolumn{6}{|c|}{ Perlakuan (Treat ments) } \\
\hline & A & B & C & D & E & $\mathbf{F}$ \\
\hline $\begin{array}{l}\text { Suhu } \\
\text { Temperature }\left({ }^{\circ} \mathrm{C}\right)\end{array}$ & $28-30$ & $28-30$ & $28-29$ & $28-31$ & $27-30$ & $27-30$ \\
\hline $\mathrm{pH}$ & $7.1-7.5$ & 7.0-7.5 & 7.0-7.5 & 7.0-7.5 & $6.5-7.0$ & $6.5-7.0$ \\
\hline $\begin{array}{l}\text { Oksigen te rlarut } \\
\text { Dissolved oxygen (mg/L) }\end{array}$ & $5.64-10.23$ & 4.94-10.59 & $6.35-10.59$ & $5.34-10.23$ & $8.47-10.53$ & $7.41-09.17$ \\
\hline $\mathrm{BOD}_{5}(\mathrm{mg} / \mathrm{L})$ & 6.71 & 5.65 & 7.76 & 7.06 & 7.41 & 8.12 \\
\hline $\begin{array}{l}\text { Amonia-N } \\
N \text {-Ammonium (mg/L) } 10^{-2}\end{array}$ & $5.34-7.98$ & $4.81-5.80$ & $1.63-4.64$ & $1.20-2.17$ & $1.92-4.83$ & $1.62-3.60$ \\
\hline $\begin{array}{l}\text { Nitrit-N } \\
N \text {-Nitrite }(\mathrm{mg} / \mathrm{L}) 10^{-2}\end{array}$ & $0.09-0.11$ & $0.04-0.13$ & $0.08-0.14$ & $0.06-0.13$ & $0.03-0.16$ & $0.06-0.22$ \\
\hline $\begin{array}{l}\text { Nitrat-N } \\
\text { N-Nitrate }(\mathrm{mg} / \mathrm{L}) 10^{-2}\end{array}$ & $0.19-0.34$ & $0.17-0.45$ & $0.15-0.65$ & $0.15-0.41$ & $0.14-0.48$ & $0.12-0.61$ \\
\hline
\end{tabular}

Keterangan (Note):

A. zeolit 100\%, B. zeolit $75 \%+$ bioball $25 \%$, C. zeolit $50 \%+$ bioball $50 \%$, D. zeolit $25 \%+$ bioball $75 \%$, E. bioball $100 \%$, dan F. serat kapas (cotton fibers)

yang digunakan, menurut Keiser $\&$ Wheaton (1983), media biofilter akan menyediakan permukaan sebagai media tumbuh bagi mikroorganisme. Untuk itu, media biofilter sangat dipengaruhi oleh ukuran dan bentuk bahan yang digunakan karena akan mempengaruhi besar kecilnya populasi mikroorgainisme selama proses nitrifikasi. Pemakaian bahan filter yang tepat akan menentukan keberhasilan pemeliharaan ikan di dalam sistem resirkulasi. Hal ini dikarenakan akan menentukan pertumbuhan bakteri non-patogen pada filter sehingga air yang dihasilkan akan menjadi tolok ukur keberhasilan sistem.

\section{Percobaan Utama}

Percobaan utama akan menggambarkan kinerja media biofilter yang digunakan untuk memelihara ikan secara langsung. Kinerja yang akan dicapai adalah kondisi air pemeliharaan tetap optimum untuk pemeliharaan ikan hias red rainbow yang dipelihara dalam sistem resirkulasi. Salah satu parameter yang dapat digunakan sebagai indikator kinerja media biofilter adalah penggunaan oksigen terlarut. Oksigen terlarut digunakan oleh bakteri dalam mengoksidasi bahan organik, proses tersebut memanfaatkan bakteri Nitrosomonas dan 
Nitrobakter yang bekerja selama proses nitrifikasi. Hasil pengukuran proses oksidasi bahan organik media biofilter zeolit $75 \%$ dan bioball 25\% mampu mengoksidasi amonia menjadi nitrat dan nitrit dengan kinerja efisiensi $95,03 \pm 0,31 \%$ selengkapnya hasil oksidasi kualitas air disajikan dalam Tabel 8. Menurut Loren \& Carter (1979) dalam Azwar (1984), berdasarkan kapasitas reoksigenasi secara alami, batas minimum BOD untuk kelayakan bagi biota air adalah $5 \mathrm{mg} / \mathrm{L}$. Jadi nilai BOD yang diperoleh selama percobaan masih layak untuk kegiatan budidaya. Selain oksigen terlarut yang digunakan untuk proses oksidasi, faktor lain juga berperan dalam proses tersebut. Keasaman dan suhu merupakan salah satu faktor yang berperan selama proses oksidasi, hasil pengukuran menunjukkan nilai keasaman pada kisaran 7,0-8,3; suhu $26^{\circ} \mathrm{C}-30^{\circ} \mathrm{C}$. Hasil kinerja media biofilter selama percobaan memberikan nilai oksidasi bahan organik amonia sebesar $95,03 \% \pm 0,31 \%$. Selengkapnya hasil tersebut disajikan dalam Tabel 6 dan 8. Hal ini sependapat dengan Suryono et al. (1997), Gutierrez \& Malone (2006), menyatakan pada kondisi pH 6,5; oksigen terlarut sebesar $2 \mathrm{mg} / \mathrm{L}$; dan suhu $28^{\circ} \mathrm{C}$ dapat menghasilkan efisiensi oksidasi bahan organik khususnya amonia sebesar $96 \%$. Gloyna (1971) dalam Linda (1995), melaporkan bahwa proses penguraian bahan organik berjalan maksimal pada suhu $25^{\circ} \mathrm{C}-35^{\circ} \mathrm{C}$.

Peningkatan kualitas air yang diperoleh berkaitan dengan semakin berkurangnya kebutuhan oksigen biokimia (deoksigenasi) selama proses perombakan bahan organik. Sejalan dengan penurunan nilai $\mathrm{BOD}_{5}$, menyebabkan ketersediaan oksigen di dalam air akan meningkat akibat oksigen yang ditransfer (reoksigenasi) akan lebih tinggi dibandingkan oksigen yang dipakai (deoksigenasi).

Menurut Kim et al. (2000), efisiensi oksidasi amonia menjadi nitrit dan nitrat sebesar $79 \%$ dengan nilai perubahan amonia $20 \mathrm{mg} / \mathrm{L}$, kinerja ini efektif terjadi pada $\mathrm{pH}$ 7,77,9. Selanjutnya media biofilter dalam sistem resirkulasi mempuyai fokus pada proses aerobik dan film filter (biofilm), Wortman \& Wheaton (1991); Malone \& Beecher (2000); Sandu et al. (2002) dalam Gutierrez \& Malone (2006), di dalamnya biofilm membutuhkan

Tabel 6. Kisaran nilai kualitas air selama percobaan utama

Table 6. The range of water quality values of various filter for main experiments

\begin{tabular}{lcccccc}
\hline \multicolumn{1}{c}{$\begin{array}{c}\text { Paramet er } \\
\text { Paramet ers }\end{array}$} & A & B & C & D & E & F \\
\cline { 2 - 7 } & $26-30$ & $26-30$ & $26-29$ & $25-31$ & $25-30$ & $25-30$ \\
\hline $\begin{array}{l}\text { Suhu } \\
\text { Temperature }\left({ }^{\circ} \mathrm{C}\right)\end{array}$ & $7.1-8.4$ & $7.0-8.3$ & $7.0-8.2$ & $7.0-8.8$ & $7.0-8.3$ & $7.0-8.0$ \\
$\mathrm{pH}$ & $5.64-10.23$ & $4.94-10.59$ & $6.35-10.59$ & $5.34-10.23$ & $8.47-10.53$ & $7.41-09.17$ \\
Oksigen terlarut \\
$\begin{array}{l}\text { Dissolved oxygen (mg/L) } \\
\text { BOD }(\mathrm{mg} / \mathrm{L})\end{array}$
\end{tabular}

Keterangan (Note):

A. zeolit $100 \%$, B. zeolit $75 \%+$ bioball $25 \%$, C. zeolit $50 \%+$ bioball $50 \%$, D. zeolit $25 \%+$ bioball $75 \%$, E. bioball 100\%, dan F. serat kapas (cotton fibers) 
substrat untuk tumbuh, oksigen sebagai energi selama proses oksidasi amonia. Selain parameter kualitas air yang terpenuhi, faktor biologi yang berperan selama proses oksidasi adalah bakteri yang berasosiasi di dalamnya, hasil perhitungan koloni bakteri yang diperoleh dalam media biofilter, media terbaik mempunyai kapadatan koloni sebanyak 8,6 $\times 10^{3}$ (cfu/mL).

Menurut Burford et al. (2003), lebih dari $40 \%$ bakteri berasosiasi dengan biofilm, meskipun keberadaanya tergantung dari suplai oksigen dari kolom air. Pada media biofilter B dengan komposisi zeolit $75 \%$ dan bioball $25 \%$, proes oksidasi didukung oleh suplai oksigen yang cukup sebesar 4,94-10,59 mg/L. Kondisi ini lebih dari cukup bahkan mengindikasikan kondisi supersaturasi, kandungan oksigen seperti ini diakibatkan adanya aliran air dari sistem dan penambahan aerasi dari aerator.

Media biofilter zeolit mempunyai fungsi ganda di dalam sistem resirkulasi, selain sebagai tempat menempel bakteri media ini juga mempunyai kemampuan secara kimiawi. Media ini mempunyai kemampuan menyerap amonia, kinerja ini dibuktikan dengan hasil oksidasi amonia paling tinggi dibanding perlakuan lain. Hal senada disampaikan oleh Wahyuni et al. (2004); Tsitsisvii (1980), Blanchard (1984) dalam Las (2007), di mana zeolit mempunyai kemampuan dalam menyerap amonia sampai $99 \%$ melalui proses kimia dengan kemampuan tukar ionnya.

\section{Kualitas Air}

Kualitas air yang optimal merupakan salah satu tujuan penggunaan sistem resirkulasi menggunakan kinerja media biofilter. Kemampuan media biofilter menjaga atau mempertahankan kualitas air yang tetap optimal bagi ikan merupakan syarat mutlak yang harus dipenuhi. Hasil output dari sistem yang ada merupakan input bagi ikan yang akan dipelihara dalam sistem tersebut. Secara lengkap hasil pengukuran kualitas air pemeliharaan ikan di akhir percobaan menunjukkan perlakuan B dalam kategori kualitas air yang baik (kategori IV), sedangkan perlakuan lain masuk kualitas air sedang (kategori III). Pengelompokan kualitas air dilakukan dengan pengukuran metode Loren \& Carter (1979) dalam Azwar (1984).

Selengkapnya kisaran dan kualitas air yang dihasilkan berdasar pengukuran kualitas air kemudian dilakukan perhitungan berdasar metode Loren \& Carter (1979) dalam Azwar (1984), setiap perlakuan selama percobaan disajikan pada Tabel 7.

Hingga akhir penelitian kualitas air perlakuan $75 \%$ zeolit $+25 \%$ bioball dan $50 \%$ zeolit $+50 \%$ bioball dapat mencapai kelas air yang dikategorikan kualitas baik (kelas IV). Perlakuan kontrol, zeolit 100\%, bioball 100\%, dan bioball $75 \%$ + zeolit $25 \%$ menghasilkan kulitas air sedang (kelas III). Menurut Las (2007), hasil percobaan oksidasi bahan organik menggunakan zeolit alam mampu mengikat amonia sebesar 99\%. Sedangkan Kusnapardi dalam Wahyuni et al. (2004), menyatakan zeolit berperan dalam pengontrol $\mathrm{pH}$ dan menyerap amoia, nitrit, nitrat, serta $\mathrm{H}_{2} \mathrm{~S}$. Kualitas air yang diperoleh selama percobaan didukung oleh beberapa faktor yang saling berkaitan dalam menentukan kualitasnya. Salah satu faktor adalah kandungan oksigen terlarut, oksigen terlarut selama penelitian cukup tinggi dengan kisaran rata-rata $(5,34$ $10,59) \mathrm{mg} / \mathrm{L}$. Hal senada dikatakan Boyd (1988), bahwa kadar oksigen terlarut minimum untuk kehidupan biota air adalah $5 \mathrm{mg} / \mathrm{L}$.

\section{Oksidasi Amonia}

Efisiensi oksidasi amonia menjadi nitrit dan nitrat menjadi tolak ukur keberhasilan bakteri Nitrobakter dan Nitrosomonas dalam mengoksidasi amonia. Menurut Mc Carty \& Haug (1971), kemampuan oksidasi bakteri dipengaruhi oleh 6 faktor yaitu: keberadaan senyawa beracun (bakterisida) air, suhu, $\mathrm{pH}$, oksigen terlarut, salinitas, dan luas permukaan untuk menempel bakteri. Hasil analisis sidik ragam terhadap oksidasi amonia antar perlakuan menunjukkan perbedaan yang nyata $(P<0,05)$. Perlakuan terbaik diperoleh perlakuan B, kinerja yang diperoleh memberikan efisiensi oksidasi amonia sebesar 95,03\% sedangkan terendah diperoleh perlakuan F dengan nilai efisiensi sebesar 55,56\%. Tingginya oksidasi amonia yang diperoleh perlakuan B didukung oleh parameter lingkungan berupa keasaman $7,0-8,3$; suhu $26^{\circ} \mathrm{C}$ $30^{\circ} \mathrm{C}$ dan nilai oksigen terlarut $4,94 \mathrm{mg} / \mathrm{L}$ kemudian nilai BOD sebesar $5,65 \mathrm{mg} / \mathrm{L}$. Sependapat dengan Gutierrez \& Malone (2006), pada kondisi keasaman 6,5; oksigen terlarut sebesar $2 \mathrm{mg} / \mathrm{L}$ dan suhu $28^{\circ} \mathrm{C}$ dapat menghasilkan oksidasi bahan organik amonia sebesar 96\%. Selanjutnya dikatakan Gloyna (1971) dalam Linda (1995), melaporkan bahwa 
Tabel 7. Pengelompokan kelas kualitas air pada akhir penelitian

Table 7. The grouping class of water quality at the end of experiments

\begin{tabular}{|c|c|c|c|c|c|}
\hline \multirow{2}{*}{$\begin{array}{l}\text { Perlakuan } \\
\text { Treatments }\end{array}$} & \multirow{2}{*}{$\begin{array}{l}\text { Kelas air } \\
\text { The class } \\
\text { of water }\end{array}$} & \multirow{2}{*}{$\begin{array}{c}\text { Sifat kualitas air } \\
\text { The character of } \\
\text { water quality }\end{array}$} & \multicolumn{3}{|c|}{ Parameter (Parameters) } \\
\hline & & & $\begin{array}{c}\mathrm{O}_{2} \\
(\mathrm{mg} / \mathrm{L})\end{array}$ & $\begin{array}{c}\text { BOD }_{5} \\
(\mathrm{mg} / \mathrm{L})\end{array}$ & $\begin{array}{c}\mathrm{NH}_{3} \\
(\mathrm{mg} / \mathrm{L})\end{array}$ \\
\hline A & 3 & Sedang (Not bad) & 8.825 & 22.591 & 0.086 \\
\hline B & 4 & Baik (Good) & 8.119 & 3.53 & 0.098 \\
\hline C & 4 & Baik (Good) & 8.472 & 3.17 & 0.417 \\
\hline $\mathrm{D}$ & 3 & Sedang (Not bad) & 7.761 & 30.361 & 0.069 \\
\hline$E$ & 3 & Sedang (Not bad) & 8.472 & 28.496 & 0.036 \\
\hline $\mathrm{F}$ & 3 & Sedang (Not bad) & 7.413 & 19.45 & 1.682 \\
\hline
\end{tabular}

Keterangan (Note):

A. zeolit $100 \%$, B. zeolit $75 \%+$ bioball $25 \%$, C. zeolit $50 \%+$ bioball $50 \%$, D. zeolit $25 \%+$ bioball $75 \%$, E. bioball 100\%, dan F. serat kapas (cotton fibers)

proses penguraian bahan organik akan berjalan maksimal pada suhu $25^{\circ} \mathrm{C}-35^{\circ} \mathrm{C}$. Bakteri nitrifikasi tumbuh optimum pada suhu $27^{\circ} \mathrm{C}$ $28^{\circ} \mathrm{C}$ (Yoshida, 1967 dalam Spotte, 1979).

Hasil pemanfaatan oksigen terlarut selama oksidasi tertinggi diperoleh perlakuan B sebesar $82,05 \%$ dan terendah $26,19 \%$. Oksigen yang digunakan selama proses oksidasi menggambarkan jumlah bakteri yang bekerja, semakin banyak oksigen yang dimanfaatkan menunjukkan kinerja yang lebih tinggi. Hal ini didukung dengan jumlah koloni bakteri yang diperoleh perlakuan $B$ dengan jumlah tertinggi sebesar $8,6 \times 10^{6} \mathrm{cfu} / \mathrm{mL}$ sedangkan yang terendah diperoleh perlakuan $F$ sebesar 3,3 $x$ $10^{6} \mathrm{cfu} / \mathrm{mL}$. Sedangkan perlakuan $\mathrm{F}$ mengindikasikan proses nitrifikasi terendah dengan konsumsi oksigen 26,19\% (Tabel 8). Menurut Burford et al. (2003), konsumsi oksigen selama proses oksidasi bahan organik di bawah 20\% mengindikasikan rendahnya proses nitrifikasi terhadap amonia menjadi nitrit dan nitrat. Rendahnya efisiensi amonia menunjukkan kinerja bakteri dalam mengoksidasi amonia dalam sistem yang ada rendah sehingga menghasiklan kualitas air yang kurang optimal. $\mathrm{Hal}$ ini didukung dengan hasil analisis koloni bakteri yang terdapat dalam filter menunjukkan bakteri diperlakuan $\mathrm{F}$ terendah.

Proses oksidasi yang terjadi tidak terlepas dari kinerja bakteri yang mempunyai peran dan fungsi yang berbeda. Salah satu bakteri yang diharapkan selama oksidasi amonia adalah Nitrobacter sp., organisme ini hidup pada kisaran $\mathrm{pH}$ 6,5-8,5; hidup di habitat tanah, air tawar dan laut, Buchanan \& Gibbons (1974) dalam Linda (1995). Genus Nitrobacter sp. sel berbentuk batang pendek, sering berbentuk baji dengan penutup polar dari Cytomembrane. Spotte (1979) menyatakan, oksidasi amonia dan nitrit terjadi pada kisaran keasaman 7,1-7,8 sedangkan proses nitrifikasi di air laut akan berhenti pada $\mathrm{pH}$ 5,5 dan genus Nitrosomonas sp., mempunyai ciriciri antara lain: sel berbentuk batang lurus dengan membran peripheral, terdapat lamela berbentuk pita. Hasil identifikasi jenis bakteri, di setiap perlakuan ditemukan bakteri berbentuk basil yang masuk ke dalam jenis Bacillus sp. Bakteri ini merupakan gram positif dalam kelas bakteri hetrotropik, yaitu bersifat uniseluler, termasuk jenis organisme redusen atau yang biasa dikenal sebagai dekomposer (Rheinheimer, 1980). Menurut Kawai et al. dalam Spotte (1979), oksidasi amonia dan nitrit lebih efisien pada kondisi aerob, selama oksidasi bahan organik dan anorganik langsung dimanfaatkan oleh bakteri sehingga kondisi ini lebih menguntungkan dan efisien secara waktu sehingga proses perbaikan kualitas air akan selalu berjalan dengan optimal. Beberapa jenis bakteri ini menghasilkan enzim ekstraseluler yang dapat menghidrolisis protein dan polisakarida kompleks.

Selama pengamatan di dalam media biofilter banyak ditemukan bakteri yang masuk ke dalam gram negatif, hal ini senada yang dikatakan oleh Burford et al. (2003), bakteri gram negatif di dalamnya termasuk Ntrobacter 


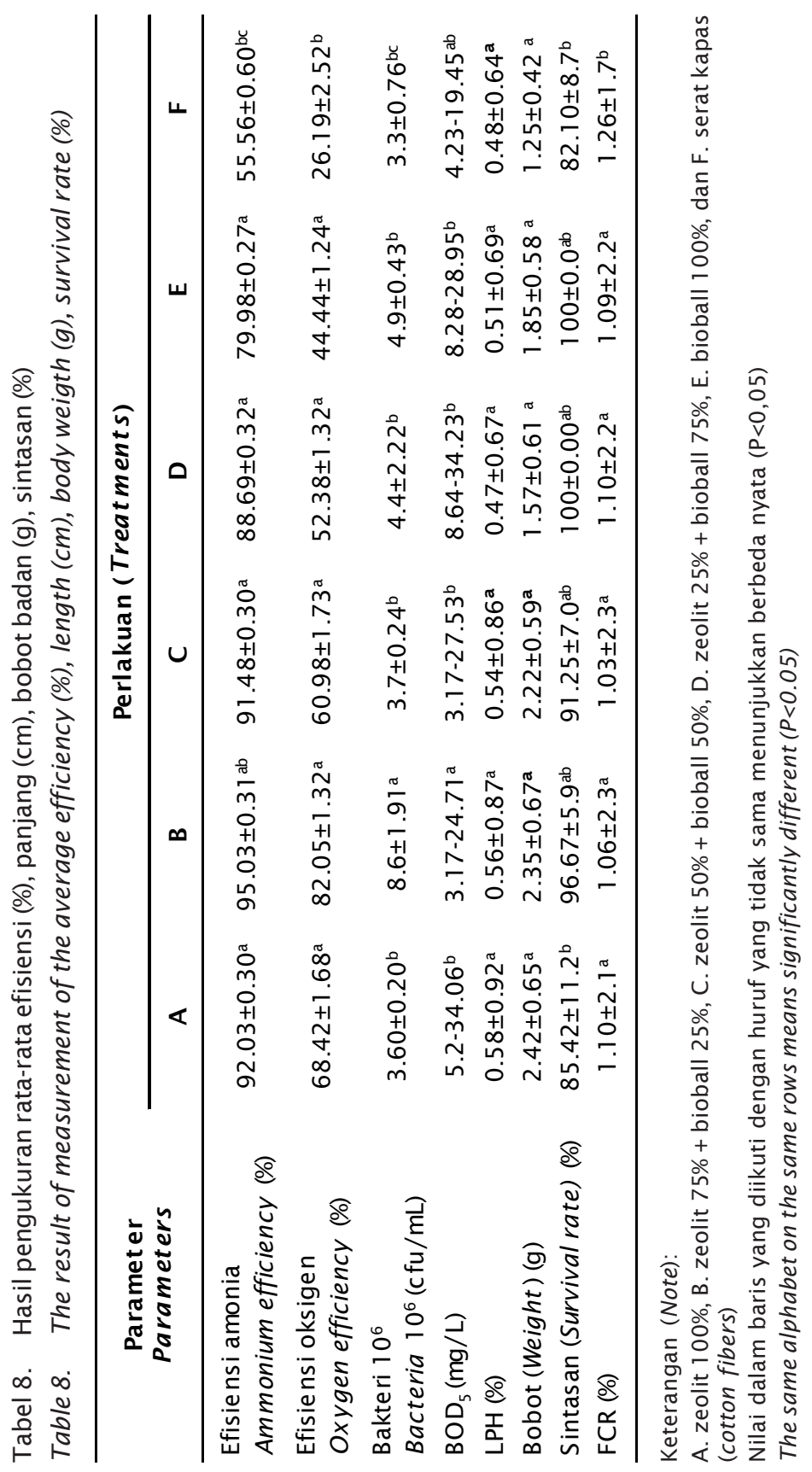


sp. dan Nitrosomonas sp. merupakan bakteri hetrotrop yang mengoksidasi amonia menjadi nitrit dan nitrat. Selanjutnya Spotte (1979) menyatakan bahwa nitrifikasi merupakan proses oksidasi amonia secara biologis menjadi nitrit dan nitrat oleh bakteri autrotof. Bakteri yang berperan di dalamnya yaitu Nitrosomonas sp. dan Nitrobacter sp., bakteri ini tidak dapat mengoksidasi subtrat selain $\mathrm{NH}_{4}^{+}$dan $\mathrm{NO}_{2}^{-}$(Mc Carty \& Haug, 1971). Menurut Burford et al. (2003), pertumbuhan optimum bakteri nitrifikasi memerlukan kadar $22 \%$ oksigen, konsumsi oksigen di bawah $20 \%$ mengindikasikan rendahnya proses nitrifikasi. Sehingga hasil pengamatan konsumi oksigen perlakuan $\mathrm{F}$ mengindikasikan proses nitrifikasi terendah dengan konsumsi oksigen 26,19\% (Tabel 8).

Selanjutnya dinyatakan, bahwa ion $\mathrm{H}^{+}$ yang yang dibebaskan selama proses nitrifikasi akan menurunkan $\mathrm{pH}$ air dan mengurangi keseimbangan karbonat. Bakteri nitrifikasi tumbuh optimum pada suhu $27^{\circ} \mathrm{C}$ $28^{\circ} \mathrm{C}$ Yosida (1967) dalam Spotte (1979), dan aktivitasnya menurun dengan naik atau turunnya salinitas. Sedangkan menurut Lyssenko \& Wheaton (2006), kualitas air optimum yang menunjang kinerja biofilm secara optimal pada $\mathrm{pH} 6-9$, total amonia $0,5-4,0$ $\mathrm{mg} / \mathrm{L}$ dan suhu $15^{\circ} \mathrm{C}-35^{\circ} \mathrm{C}$.

Hasil pengukuran koloni bakteri selama percobaan menunjukkan kepadatan setiap kombinasi filter yang digunakan menghasilkan jumlah bakteri yang berbeda-beda. Analisis sidik ragam menunjukkan koloni bakteri perlakuan $B$ berbeda nyata $(P<0,05)$. Hasil pengamatan terbaik diperoleh perlakuan $B$ dengan kepadatan koloni bakteri sebesar $(8,6 \pm 1,91) \times 10^{6}$, hal ini menunjukkan adanya kerja bakteri yang lebih besar dibanding perlakuan lain. Kinerja bakteri ditandai dengan adanya penurunan kadar $\mathrm{BOD}_{5}$ sampai 3,17 $\mathrm{mg} / \mathrm{L}$ dan amonia $0,0057 \mathrm{mg} / \mathrm{L}$, dengan

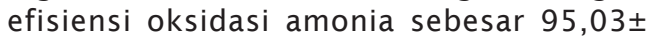
$0,31 \%$.

\section{Pertumbuhan Ikan}

Hasil pengamatan dan pengukuran laju pertumbuhan harian (LPH), sintasan $(\mathrm{KH})$, efisiensi pakan (FCR). Hasil pengukuran pertumbuhan ikan antar perlakuan tidak memberikan perbedaan yang nyata sedangkan untuk sintasan antar perlakuan terjadi perbedaan antar perlakuan. Perlakuan B memberikan pertumbuhan harian terbaik dengan rata-rata $0,56 \pm 0,87 \mathrm{~cm}$ dengan sintasan 96,67\%. Hal ini dapat dikaitkan dengan hasil perolehan perbaikan kualitas air menggunakan filter $75 \%$ zeolit $+25 \%$ bioball menghasilkan kualitas air dengan kategori baik. Menurut Loren \& Carter dalam Azwar (1984), kualitas air yang baik didukung dengan ketersediaan oksigen terlarut $8,12 \mathrm{mg} / \mathrm{L}$ dengan nilai pemanfaatan oksigen sebesar $82,05 \%$ dan oksidasi amonia sebesar 95,03\%. Selengkapnya nilai kualitas air hasil kinerja biofilter disajikan pada Tabel 8. Hasil ini memberikan output berupa kualitas air yang tetap terjaga sehingga menghasilkan pertumbuhan ikan red rainbow dengan hasil yang tinggi.

Menurut Effendie (2002), pertumbuhan dipengaruhi oleh beberapa faktor antara lain: kepadatan, ukuran makanan yang tersedia, kualitas air, umur, ukuran ikan, dan kematangan gonad. Pertumbuhan merupakan salah satu parameter untuk mengetahui perubahan ukuran ikan baik bobot, panjang, dan volume dalam perubahan waktu (Weatherley, 1972). Hasil yang diperoleh menunjukkan perbedaan pertumbuhan di masing-masing perlakuan dikarenakan adanya kompetisi kualitas air dan ruang gerak.

Makanan tambahan merupakan salah satu unsur terpenting dalam menunjang keberhasilan budidaya intensif, karena makanan alami tidak lagi mencukupi untuk pertumbuhan (Hickling, 1971). Pemberian pakan untuk setiap perlakuan dengan konversi pakan (FCR) terbesar di perlakuan $F(1,25 \%)$, diikuti $A$ dan $D(1,1 \%)$ kemudian $B, C$, dan E sebesar $1,03 \%$ dan $1,09 \%$. Konversi pakan (FCR) untuk perlakuan $\mathrm{F}$ menunjukkan makanan yang diberikan kurang efisien sehingga selama percobaan pertumbuhannya lambat (Tabel 8). Menurut Hickling (1971), makanan yang diberikan berfungsi untuk memelihara tubuh dan mengganti alat yang rusak, sedangkan kelebihannya digunakan untuk pertumbuhan. Kualitas air yang baik akan memberikan tempat yang nyaman bagi biota air terutama ikan sehingga proses metabolisme berjalan maksimal yang akan menghasilkan energi yang cukup untuk pemeliharaan dan kelebihannya diperlukan untuk pertumbuhan dan reproduksi (Wedemeyer, 1996).

\section{KESIMPULAN DAN SARAN}

Kombinasi media biofilter menggunakan kombinasi bahan zeolit $75 \%$ dan bioball $25 \%$ 
mampu menghasilkan kualitas air terbaik dengan efisiensi oksidasi amonia sebesar 95,03\%; dengan kualitas air kategori baik. Kualitas air yang baik akan menunjang proses metabolisme secara optimum sehingga menghasilkan pertumbuhan, sintasan ikan rainbow merah terbaik.

Pada penelitian ini tidak dikaji mengenai Iama ketahanan filter, maka diperlukan penelitian lanjutan mengenai lamanya ketahanan filter dalam memperbaiki kualitas air.

\section{DAFTAR ACUAN}

Azwar, Z.I. 1984. Peranan Sistem Biofilter dan Kapur dalam Proses Reklamasi air Bekas Pemeliharaan Ikan Mas. Fakultas Pascasarjana. IPB, Bogor, $67 \mathrm{hlm}$.

Burford, M.A., Tompson, P.J., Mc Intosh, R.P., Bauman, R., \& Pearson, D.C. 2003. Nutrient and Microbial Dynamics in High-Intensity, Zero-exchange Shrimp Ponds in Belize. Aquaculture, 219: 393-411.

Boyd, C.E. 1988. Water Quality in Warm Water Fish Pond. Fourth Printing. Auburn University Agricultural Experiment Station, Alabama, USA, $359 \mathrm{pp}$.

Effendie, M.I. 2002. Biologi Perikanan. Yayasan Pustaka Nusatama. Yogyakarta, $163 \mathrm{hlm}$.

Gutierrez-Wing, M.T. \& Malone, R.F. 2006. Biological filters in aquaculture: Trends and research directions of freshwater and marine applications. Department of Civil and Environmental Enginering, Louisiana State University, Baton Riouge, LA. USA, 34: 163-171.

Hickling, C.F. 1971. Fish Culture. Faber and Faber London, $15 \mathrm{pp}$.

Keiser, G.E. \& Wheaton, F.W. 1983. Nitrification Filter For Aquatic Culture System: State of Art. J. World Maricul. Soc., 14: 39-324.

Kim, Sung-Koo, Kong, I., Lee, B.H, \& Kang, L. 2000. Removal of Ammonium-N From Recirculation Aquaculture System Using an Immobilized Nitrifier. Aquaculture Engineering, 21: 139-150.

Las, T. 2007. Potensi Zeolit untuk Mengolah Limbah Industri dan Radioaktif. Pusat Teknologi Limbah Radioaktif-Badan Tenaga Nuklir Nasional. Jakarta, $3 \mathrm{hlm}$.

Linda. 1995. Kajian Kinerja Bakteri Terhadap Air Limbah Organik di Waduk Setiabudi. Jakarta. Tesis. Sekolah Pascasarjana, IPB, $96 \mathrm{hlm}$.
Lyssenko, C. \& Wheaton, F. 2006. Impact of Rapid Impulse Operating Distrubance on Ammonia Removal by Trikling and Submerged-Uplow Biofilter for Intensif Recircualting Aquaculture. Aquaculture Engineering, 35: 38-50.

Masser, M.P., Rokocy, J., \& Losordo, T.M. 1999. Recirculating Aquaculture Tank Production System. Management of Recirculating System. SRAC Publication No. 452 USDA, $12 \mathrm{pp}$.

Mc Carty, P.L. \& Haug, R.T. 1971. Nitrogen Removal for Waste Water by Biological Nitification. The Society for Applied Bacterological Sympocium Series No. 1. Academic Press, London.

Muir, J.F. 1994. Water Reuse System in Aquaculture. Infofish International, 6: 40-48.

Rheinheimer. 1980. Aquatic Microbiology, A. Willey Inter Scince Publication Chichester, $225 \mathrm{pp}$.

Sawyer, C.N. \& Mc Carty, P. 1978. Chemistry for Enviromental Engineering. Mc Graw-Hill, $3^{\text {th }}$ Edition, United State of America.

Spotte, S. 1979. Fish and Invertebrate Culture. Water Management in Closed System. Second edition. Jhon Willey and Sons, New York, $179 \mathrm{pp}$.

Steel, R.G.D. \& Torrie, J.H. 1991. Principles and Procedures of Statistics. A Biometrical approach. Seconded. Mc. Graw Hill International Book Company. Sydney, 633 pp.

Soemantojo, R.W. 1998. Kapasitas Absorbsi Zeolit Alam dan $\mathrm{H}$-Zeolit Terhadap Larutan Ammonia dalam Reaktor Batch Tunggal. Fakutas Teknik Kimia. UI. Depok, J. Teknologi, XII(1): 45-46.

Tanjung, L.R. 1994. Pengaruh Lama Penyimpanan Terhadap Kemampuan Inokulasi Bioesfer Sistem Aliran Tertutup. Limnostek Perairan Daerah Tropis Indonesia, VI(2): 16 19.

Wahyuni, E., Mudasir, \& Diah, N.L. 2004. Kajian Fotoreduksi lon Cr (VI) Terkatalisis Oksidasi Zn (II) dalam Pengemban Zeolit Alam. J. Kimia Lingkungan, 5(1): 21-24.

Wedemeyer, G.A. 1996. Physiology of fish in intensive culture system. Chapman and Hall. Printed in the United Stated of America, $232 \mathrm{pp}$.

Weatherley, A.H. 1972. Growth and Ecology of Fish Population, Academic Press. New York, 158 pp. 